\title{
PENGARUH PUPUK HAYATI DAN TANAMAN JARAK PAGAR (Jatropha curcas L.)TERHADAP PENYERAPAN LOGAM BERAT TEMBAGA (Cu) DAN TIMBAL (Pb) PADA LAHAN BERPASIR
}

\author{
Sudaryono \\ Peneliti di Pusat Teknologi Lingkungan \\ Badan Pengkajian dan Penerapan Teknologi
}

\begin{abstract}
In general, coastal areas have the physical and chemical properties of less fertile land with an extreme dry climate, so that only a few plants that can live, including Jatropha curcas L. To enhance fertility and improve soil physical properties, need the addition of organic fertilizer. Source of compost can be derived from a variety of wastes, including household waste and landfill. Quality compost landfill taken from Piyungan, Yogyakarta, has a high content of organic $\mathrm{C}, \mathrm{pH}$ neutral, low $\mathrm{N}$ concentration, with the ratio $\mathrm{C} / \mathrm{N}$ is very high. But compost landfill has an obstacle in the form of heavy metal containing high $\mathrm{Cu}$ and $\mathrm{Pb}$. To prevent accumulation heavy metals into plant tissue or clean up heavy metals from the soil it was attempted by phytoremediation using jatropha plantation and bio-fertilizer that contains bacteria Azotobacter sp and Pseudomonas sp.

From the research results can be informed that: (1) The city compost and biological fertilizers, can increase soil fertility with increasing nutrient content in soil. (2) Biofertilizers could inhibit the accumulation of copper $(\mathrm{Cu})$ and lead $(\mathrm{Pb})$ into Jatropha curcas L., (3) Jatropha plant can be classified as phytoremediation plants, because it can absorption heavy metals into leaf tissue.
\end{abstract}

Key words: landfill compost, bio fertilizer, jatropha plants, heavy metals

\section{PENDAHULUAN}

Daerah pantai pada umumnya merupakan kawasan pasir dengan ciri porositas tanah tinggi, iklim kering yang sangat ekstrim, sifat fisik dan kimia tanahnya kurang mendukung, miskin unsur hara, kecepatan anginnya sangat tinggi dan faktor-faktor lainnya yang kurang bersahabat sehingga kawasan pantai kurang cocok untuk dikembangkan menjadi kawasan pertanian ${ }^{1}$. Akibatnya hanya beberapa tanaman yang dapat bertahan hidup, diantaranya adalah tanaman jarak pagar (Jatropha curcas L.). Tanaman jarak pagar merupakan tanaman yang mampu hidup di daerah tropis yang kering dengan curah hujan tahunan antara 300-1000 mm.

Dalam kaitannya dengan daya menyimpan air, tanah pasiran mempunyai daya pengikatan terhadap lengas tanah relatif rendah karena permukaan kontak antara tanah pasiran didominasi oleh poripori mikro. Oleh karena itu air yang jatuh pada permukaan tanah pasiran akan segera mengalami perkolasi dan air kapiler akan mudah lepas karena evaporasi. Salah satu cara untuk meningkatkan kualitas tanah pasiran adalah dengan menambah bahan pengkondisi tanah berupa pupuk kompos 
atau pupuk organik lainnya yang berfungsi menaikkan daya penyimpanan air dan memperbaiki kualitas tanah ${ }^{2,3}$.

Sumber kompos dapat berasal dari berbagai limbah, diantaranya limbah rumah tangga dan sampah kota (TPA). Secara kimia, kompos dapat meningkatkan kapasitas tukar kation (KTK) dan ketersediaan unsur hara dalam tanah. Secara biologi, kompos merupakan bahan organik yang menjadi sumber makanan bagi mikroorganisme tanah. Adanya kompos dapat mempercepat perkembangan fungi, bakteri, serta mikroorganisme lainnya sehingga yang menguntungkan berkembang lebih cepat. Banyaknya mikroorganisme tanah dapat menambah kesuburan tanah'1). Pupuk kompos yang berupa pupuk kandang atau pupuk dari sampah (sampah kota) adalah merupakan hasil perombakan bahan organik oleh mikrobia dengan hasil akhir pupuk organik yang memiliki nisbah $\mathrm{C} / \mathrm{N}$ rendah.

Pupuk kompos TPAberasal dari berbagai sumber, maka tidak menutup kemungkinan bahwa sampah TPA mengandung logam berat yang berasal dari limbah buangan yang sengaja dibuang oleh industri. Tingginya material logam pencemar pada kompos TPA seperti timbal $(\mathrm{Pb})$, tembaga $(\mathrm{Cu})$, kadmium (Cd), kromium (Cr), dan nikel (Ni) dapat berpengaruh terhadap tanah dan tanaman yang tumbuh di atasnya. Menurut Notohadiprawiro (1995), penyerapan logam berat oleh tanaman dipengaruhi oleh berbagai faktor, antara lain: tanah dan biologi tanaman (jenis, fase pertumbuhan dan fase perkembangan tanaman) ${ }^{4)}$.

Logam berat terserap kedalam jaringan tanaman melalui akar yang selanjutnya masuk kedalam siklus rantai makanan (Alloway, 1999 dalam Charlena, 2004) ${ }^{(5)}$. Logam akan terakumulasi pada jaringan tubuh dan dapat menimbulkan keracunan bagi manusia, hewan, dan tumbuhan apabila melebihi batas toleransi. Akumulasi logam berat ke dalam jaringan tanaman dapat secara langsung mempengaruhi laju pertumbuhan dan hasil tanaman serta secara tidak langsung dapat mempengaruhi kesehatan manusia, jika mengkonsumsi makanan yang telah terkontaminasi logam berat. Pengkajian akumulasi logam ke dalam tanaman tahunan akan lebih aman karena tanaman tahunan atau tanaman industri banyak yang tidak dimanfaatkan sebagai bahan konsumsi manusia. Salah satu tanaman industri yang tidak dikonsumsi manusia yaitu tanaman jarak pagar (Jatropha curcas L.).

Penghambatan akumulasi logam berat ke dalam jaringan tanaman dapat dilakukan dengan memanfaatkan mikrobia sebagai pupuk hayati. Beberapa bakteri dari genus Azotobacter sp. dan Pseudomonas sp. mampu menghambat translokasi logam berat di dalam tanah dan mampu menghasilkan zat pengatur tumbuh pada tanaman').

Bahan organik peranannya sangat penting dalam menekan ketersediaan logam berat di dalam tanah. Serapan logam $\mathrm{Cd}, \mathrm{Cu}$, $\mathrm{Pb}, \mathrm{Zn}$, dan $\mathrm{Cr}$ ditemukan lebih rendah di tanah organik dibandingkan tanah mineral2). Pupuk organik dan pupuk hayati dapat digunakan untuk menahan logam berat agar tetap berada di dalam tanah sehingga tidak diserap oleh akar tanaman, atau sebaliknya dapat berfungsi untuk mempercepat proses penyerapan logam berat ke jaringan tanaman sehingga lahan yang tercemar akan dapat terpulihkan kembali.

Beberapa pupuk hayati yang digunakan untuk meningkatkan pertumbuhan dan hasil tanaman, merupakan formulasi beberapa bakteri yang memiliki fungsi tertentu terhadap tanaman. Penambat $\mathrm{N}$ atmosfer oleh mikrobia dapat membantu ketersediaan unsur $\mathrm{N}$ bagi tanaman dan dapat mengefisienkan penggunaan pupuk $\mathrm{N}$ yang berasal dari pupuk organik. Azotobacter sp. merupakan salah satu mikrobia yang dapat menambat $\mathrm{N}$ atmosfer baik sebagai organisme yang hidup bebas atau berasosiasi dengan akar tanaman ${ }^{6}$. Pseudomonas sp. merupakan mikrobia tanah yang mempunyai kemampuan melarutkan $\mathrm{P}$ tidak tersedia menjadi tersedia. $\mathrm{Hal}$ ini karena bakteri tersebut mengeluarkan 
asam-asam organik yang dapat membentuk komponen stabil dengan kation-kation mengikat $\mathrm{P}$ di dalam tanah.

\subsection{Tujuan}

Penelitian ini untuk mengetahui besarnya akumulasi logam berat $\mathrm{Cu}$ (tembaga) dan $\mathrm{Pb}$ (timbal) pada jaringan tanaman jarak pagar (Jatropha curcas L.) oleh karena pengaruh fitoremediasi dan stabilisasi pupuk hayati.

\section{METODE PENELITIAN}

\subsection{Waktu dan Tempat}

Penelitian dilaksanakan pada bulan Juli sampai Desember 2007, dengan tempat di lahan berpasir selatan Pulau Jawa, di daerah Patihan, Bantul, Yogyakarta.

\subsection{Bahan Penelitian}

Bahan penelitian yang digunakan antara lain : tanaman Jarak Pagar (Jatropha curcas L.) berumur 3 bulan, dengan tinggi antara 40-50 cm, ditanam dengan jarak tanam 1,5 m x 1,5 m. Kompos kota diambil dari TPA Piyungan, Yogyakarta. Pupuk hayati (BIOCON) yang digunakan diberasal dari Laboratorium Mikrobiologi, Fakultas Pertanian, Universitas Gadjah Mada, pupuk tersebut mengandung bakteri Azotobacter sp. dan Pseudomonas sp., dan pupuk NPK.

\subsection{Metodologi}

Metodologi penelitian menggunakan rancangan split plot yang diatur dalam Rancangan Acak Lengkap dengan 3 blok sebagai ulangan. Faktor pertama yang berfungsi sebagai main plot yaitu pemberian pupuk hayati, terdiri dari 2 aras, yaitu:

a. Tanpa pupuk hayati (B0)

b. Diberi pupuk hayati (B1)
Faktor kedua yang berfungsi sebagai sub plot yaitu kombinasi kompos sampah kota dengan pupuk NPK, terdiri dari 4 perlakuan, yaitu:

Kompos sampah kota: pupuk NPK $=1: 0$ (P1)

Kompos sampah kota: pupuk NPK $=2 / 3: 1 / 3(P 2)$

Kompos sampah kota: pupuk NPK $=1 / 3: 2 / 3(P 3)$

Kompos sampah kota : pupuk NPK $=0: 1$ (P4)

Keterangan :

Kompos sampah kota kering oven

$$
\begin{aligned}
1 \text { bagian } & =6,6 \text { ton } / \mathrm{ha} \rightarrow 1,5 \mathrm{~kg} / \text { tanaman } \\
2 / 3 \text { bagian } & =4,4 \text { ton } / \mathrm{ha} \rightarrow 1 \mathrm{~kg} / \text { tanaman } \\
1 / 3 \text { bagian } & =2,2 \text { ton } / \mathrm{ha} \rightarrow 0,5 \mathrm{~kg} / \text { tanaman } \\
0 \text { bagian } & =\text { tanpa kompos }
\end{aligned}
$$

$$
\begin{aligned}
& \text { Pupuk NPK } \\
& 1 \text { bagian }=88,88 \mathrm{~kg} / \text { ha Urea (20 gram/tanaman) }
\end{aligned}
$$

Jadi terdapat 8 kombinasi perlakuan, yakni :

\begin{tabular}{|c|l|c|c|c|c|c|}
\hline 1. & $\begin{array}{l}\text { Kompos tanpa } \\
\text { pupuk hayati }\end{array}$ & + & NPK & $=$ & $1: 0$ & $(\mathrm{~B} 0 \mathrm{P} 1)$ \\
\hline 2. & $\begin{array}{l}\text { Kompos tanpa } \\
\text { pupuk hayati }\end{array}$ & + & $\mathrm{NPK}$ & $=$ & $2 / 3: 1 / 3$ & $(\mathrm{~B} 0 \mathrm{P} 2)$ \\
\hline 3. & $\begin{array}{l}\text { Kompos tanpa } \\
\text { pupuk hayati }\end{array}$ & + & $\mathrm{NPK}$ & $=$ & $1 / 3: 2 / 3$ & $(\mathrm{~B} 0 \mathrm{P} 3)$ \\
\hline 4. & $\begin{array}{l}\text { Kompos tanpa } \\
\text { pupuk hayati }\end{array}$ & + & $\mathrm{NPK}$ & $=$ & $0: 1$ & $(\mathrm{~B} 0 \mathrm{P} 4)$ \\
\hline 5. & $\begin{array}{l}\text { Kompos + pupuk } \\
\text { hayati }\end{array}$ & + & $\mathrm{NPK}$ & $=$ & $1: 0$ & $(\mathrm{~B} 1 \mathrm{P} 1)$ \\
\hline 6. & $\begin{array}{l}\text { Kompos + pupuk } \\
\text { hayati }\end{array}$ & + & $\mathrm{NPK}$ & $=$ & $2 / 3: 1 / 3$ & $(\mathrm{~B} 1 \mathrm{P} 2)$ \\
\hline 7. & $\begin{array}{l}\text { Kompos + pupuk } \\
\text { hayati }\end{array}$ & + & $\mathrm{NPK}$ & $=$ & $1 / 3: 2 / 3$ & $(\mathrm{~B} 1 \mathrm{P} 3)$ \\
\hline 8. & $\begin{array}{l}\text { Kompos + pupuk } \\
\text { hayati }\end{array}$ & + & $\mathrm{NPK}$ & $=$ & $0: 1$ & $(\mathrm{~B} 1 \mathrm{P} 3)$ \\
\hline
\end{tabular}


Percobaan menggunakan blok sebagai ulangan, tiap ulangan terdiri dari 8 petak (kombinasi perlakuan). Ukuran masingmasing petak $54 \mathrm{~m}^{2}$, tiap petak ditanam 35 batang tanaman, dengan ketentuan 3 tanaman dijadikan tanaman korban (tanaman yang dengan sengaja dicabut untuk dijadikan obyek pengamatan/penelitian). Pemberian pupuk hayati dilakukan bersamaan dengan pemberian kompos yaitu pada setiap lubang tanam ketika penanaman, begitu pula kombinasi $\mathrm{N}$, $\mathrm{P}$, dan $\mathrm{K}$ yang diberikan hanya saat penanaman pada setiap lubang tanamnya. Pengambilan tanaman sampel dilakukan setelah tanaman berumur 24 minggu setelah tanam (MST), dengan cara membongkar tanaman dengan hati-hati agar akar tanaman tidak terusik.

\subsection{Pengamatan}

1. Analisis awal

a. Analisis tanah

Analisis tanah dilakukan pada saat awal persiapan Iahan. Sampel tanah diambil dan dianalisis di laboratorium IImu Tanah, Fakultas Pertanian, UGM dan di laboratorium Kimia, Fakultas MIPA, UGM. Analisis yang dilakukan yaitu kadar lengas, $\mathrm{pH}$, kadar bahan organik, kadar $\mathrm{N}$, kadar $\mathrm{P}$, kadar $\mathrm{K}$, dan kadar logam (Cu dan $\mathrm{Pb}$ ).

b. Analisis kompos sampah kota Analisis kompos sampah kota dilakukan sebelum diaplikasikan ke lahan. Sampel kompos sampah kota (TPA) dianalisis di Laboratorium Ilmu Tanah, Fakultas Pertanian, UGM dan di laboratorium Kimia, Fakultas MIPA, UGM. Analisis yang dilakukan yaitu kadar lengas, $\mathrm{pH}$, kadar bahan organik, kadar $\mathrm{N}$, kadar $\mathrm{P}$, kadar K, dan kadar logam (Cu dan $\mathrm{Pb}$ ).
2. Analisis akhir

a. Analisis jaringan tanaman

Daun dan buah tanaman jarak pagar (Jatropha curcas L.) dianalisis untuk mengetahui besarnya logam berat $\mathrm{Pb}$ dan $\mathrm{Cu}$ yang diserap tanaman. Analisis ini dilakukan di Laboratorium IImu Tanah, Fakultas Pertanian, UGM dan di Laboratorium Kimia, Fakultas MIPA, UGM dengan menggunakan metode destruksi dan AAS (Atomic Absorbtion Spectometry).

b. Analisis tanah

Analisis tanah juga dilakukan sesudah penelitian berakhir. Sampel tanah dianalisis di Laboratorium IImu Tanah, Fakultas Pertanian, UGM dan di laboratorium Kimia, Fakultas MIPA, UGM. Analisis yang dilakukan yaitu kadar lengas, $\mathrm{pH}$, kadar bahan organik, kadar N, kadar $\mathrm{P}$, kadar $\mathrm{K}$, dan kadar logam (Cu dan $\mathrm{Pb}$ ).

\section{HASIL DAN PEMBAHASAN}

\subsection{Kompos TPA}

Hasil analisis kimia kompos sampah kota TPA Piyungan, Yogyakarta yang digunakan sebagai sumber bahan organik dapat dilihat pada Tabel 1.

Dari hasil analisis laboratorium, kualitas kompos TPA Piyungan memiliki kadar $\mathrm{C}$ organik, $\mathrm{pH}$, dan kadar $\mathrm{N}$, nisbah $\mathrm{C} / \mathrm{N}$ yang sangat tinggi melebihi batas maksimum yang diperbolehkan berdasarkan standar SNI 19-7030-2004), sehingga kompos sampah TPA Piyungan masih belum terdekomposisi secara sempurna dan diperlukan beberapa waktu lagi untuk proses perombakan sampai $\mathrm{C} / \mathrm{N}$ nya turun di bawah nisbah $\mathrm{C} / \mathrm{N}$ maksimum yang disyaratkan yaitu $10-20$. Kandungan hara $\mathrm{N}$ relatif normal, kandungan $\mathrm{P}$ rendah, dan $\mathrm{K}$ tersedia relatif rendah. 
Tabel 1. Analisis Kompos dari TPAPiyungan dan SNI 19-7030-2004

\begin{tabular}{|c|c|c|c|c|c|}
\hline \multirow{3}{*}{ No } & \multirow{3}{*}{ Parameter } & \multirow{3}{*}{ Satuan } & \multicolumn{3}{|l|}{ Nilai } \\
\hline & & & \multirow{2}{*}{$\begin{array}{l}\text { TPA } \\
\text { Piyungan }\end{array}$} & \multicolumn{2}{|c|}{$\begin{array}{l}\text { SNI 19-7030- } \\
2004\end{array}$} \\
\hline & & & & Minim & Maks \\
\hline 1 & $\mathrm{pH}$ & - & 7,1 & 6,80 & 7,49 \\
\hline 2 & $C$ & $(\%)$ & 21,66 & 9,80 & 32 \\
\hline 3 & $\mathrm{~N}$ & $(\%)$ & 1,01 & 0,40 & - \\
\hline 4 & $\mathrm{C} / \mathrm{N}$ & - & 21,4 & 10 & 20 \\
\hline 5 & $\mathrm{P}$ tersedia & $(\%)$ & 0,0158 & 0,10 & - \\
\hline 6 & $\mathrm{~K}$ tersedia & $(\%)$ & 0,028 & 0,20 & * \\
\hline 7 & $\begin{array}{l}\text { Kromium } \\
\text { (Cr) }\end{array}$ & (ppm) & 18,7 & * & 210 \\
\hline 8 & $\begin{array}{l}\text { Kadmium } \\
\text { (Cd) }\end{array}$ & (ppm) & 0,092 & * & 3 \\
\hline 9 & Seng (Zn) & (ppm) & 15,24 & * & 500 \\
\hline 10 & Nikel (Ni) & (ppm) & 0,67 & * & 62 \\
\hline 11 & $\begin{array}{l}\text { Tembaga } \\
\text { (Cu) }\end{array}$ & (ppm) & 148,4 & * & 100 \\
\hline 12 & $\begin{array}{l}\text { Timbal } \\
(\mathrm{Pb})\end{array}$ & (ppm) & 215,68 & * & 150 \\
\hline
\end{tabular}

Keterangan : * Nilainya lebih besar dari minimum atau lebih kecil dari maksimum

Kekurangan yang terjadi pada kompos TPA tersebut adalah kadar logam beratnya terutama $\mathrm{Cu}$ dan $\mathrm{Pb}$ menunjukkan kadar yang melebihi standar kualitas kompos. Kadar logam yang berlebihan akan menimbulkan pencemaran terhadap tanah, dan dapat berakibat pertumbuhan tanaman terganggu. Logam yang terdapat pada kompos sampah TPA tersebut kemungkinan disebabkan karena tidak adanya pemisahan limbah yang berasal dari bahan organik dan bahan inorganik atau dapat disebabkan karena adanya pihak industri yang sengaja membuang limbahnya ke TPA.

Namun demikian, kompos kota tersebut masih dapat dimanfaatkan sebagai pupuk organik dengan bantuan teknologi bioremediasi agar logam berat tidak terserap oleh akar tanaman atau kompos TPA tersebut digunakan memupuk lahan tandus/kritis yang direvegetasi dengan tanaman penghijauan atau tanaman industri, terutama tanaman yang bersifat sebagai fitoremedian dan tanaman tersebut tidak dimanfaatkan secara langsung untuk kepentingan manusia.

\subsection{Kimia Tanah Pasiran}

\section{1) Kemasaman Tanah $(\mathrm{pH})$}

Kemasaman $(\mathrm{pH})$ tanah dapat mempengaruhi ketersediaan hara tanah dan bisa menjadi faktor yang berhubungan dengan kualitas tanah. $\mathrm{pH}$ tanah sangat penting dalam menentukan aktivitas dan dominasi mikroorganisme tanah yang berhubungan dengan proses-proses yang sangat erat kaitannya dengan siklus hara, penyakit tanaman, dekomposisi dan sintesa senyawa kimia organik dan transpor gas ke atmosfir oleh mikroorganisme, seperti methan ${ }^{4}$.

Kisaran $\mathrm{pH}$ 6,0 - 7,3 adalah merupakan $\mathrm{pH}$ optimum, dimana $\mathrm{P}$ tersedia dalam jumlah maksimal karena pada kondisi ini kemampuan tanah mengikat $\mathrm{P}$ adalah paling rendah. Pada $\mathrm{pH}$ yang semakin rendah (sangat masam) atau semakin tinggi (sangat alkalis) jumlah P-tersedia semakin sedikit, karena semakin banyak $P$-tersedia yang diikat menjadi senyawa-senyawa yang sukar larut ${ }^{4}$.

Dari Tabel 2 memperlihatkan bahwa tanah pasiran di Patihan, Bantul, Yogyakarta, dapat diketahui bahwa $\mathrm{pH}$ tanah pada awal penelitian adalah 7,45 , setelah penelitian (tanaman berumur 24 minggu), $\mathrm{pH}$ tanah berkisar antara 7,11 (B1P3) 7,68 (B0P1). Ternyata pemberian kompos yang dikombinasikan dengan pemberian pupuk kimia (NPK) dan pupuk hayati dapat mempengaruhi kualitas tanah, meskipun tidak ada perubahan yang signifikan dengan $\mathrm{pH}$ tanah dalam keadaan netral.

\section{2) Bahan Organik dan Nitrogen}

Bahan organik adalah merupakan sumber $\mathrm{N}$ utama di dalam tanah dan berperan cukup besar dalam proses perbaikan sifat fisika, kimia dan biologi tanah. Pengaruh bahan organik terhadap kesuburan tanah akan dapat meningkatkan kapasitas pertukaran kation (KPK), kapasitas pertukaran anion, $\mathrm{pH}$ tanah, daya sangga tanah dan terhadap keharaan tanah. 
Kadar $\mathrm{N}$ tanah biasanya dikategorikan sebagai indikator untuk menentukan dosis pemupukan Urea. Gejala kekurangan $\mathrm{N}$, tanaman tumbuh kecil atau kerdil, pertumbuhan akar terbatas dan daunnya kuning. Kadar $\mathrm{N}$ total tanah di wilayah studi tergolong sangat rendah, yaitu sebesar 0,019 persen. Penambahan bahan organik ke dalam tanah dapat memperbaiki sifat-sifat tanah, khususnya untuk meningkatkan unsur hara di dalam tanah.

Kandungan bahan organik di wilayah studi umumnya rendah, yaitu $0.918 \%$ (tanah asli/awal penelitian) dan berkisar antara $(0.666-1.317) \%$ atau dengan rerata 1.254 $\%$ pada saat akhir penelitian. Peningkatan

\section{3) C/N Ratio}

$\mathrm{C} / \mathrm{N}$ rasio berfungsi untuk mengatur apakah bahan organik dalam kondisi cepat hancur atau sulit hancur. Bahan organik yang sudah menjadi kompos dapat berbentuk halus dan kasar, bahan organik halus mempunyai kadar $\mathrm{N}$ tinggi dengan $\mathrm{C} / \mathrm{N}$ ratio rendah, sedangkan bahan organik kasar mempunyai $\mathrm{N}$ rendah dengan $\mathrm{C} / \mathrm{N}$ ratio tinggi. Faktor yang mempengaruhi penghancuran bahah organik antara lain suhu, kelembaban, tata udara tanah, pengolahan tanah, $\mathrm{pH}$ dan jenis bahan organik ${ }^{4}$.

Nisbah $\mathrm{C} / \mathrm{N}$ pada tanah pasca penelitian mengalami penurunan, hal ini disebabkan

Tabel 2. Analisis Tanah Asal dan Akhir Penelitian

\begin{tabular}{|c|c|c|c|c|c|c|c|c|c|c|c|c|}
\hline \multirow{2}{*}{ No } & \multirow{2}{*}{ Parameter } & \multirow{2}{*}{ Satuan } & \multirow[t]{2}{*}{ Awal } & \multicolumn{8}{|c|}{ Pasca Penelitian } & \multirow{2}{*}{ Keterangar } \\
\hline & & & & B0P1 & BOP2 & BOP3 & BOP4 & B1P1 & B1P2 & B1P3 & B1P4 & \\
\hline 1. & $\begin{array}{l}\text { Kadar } \\
\text { Lengas }\end{array}$ & -- & 0,6435 & 0.96 & 0.94 & 0.73 & 0.68 & 1.03 & 1.07 & 0.59 & 0.75 & Rendah \\
\hline 2. & KPK & $(m e \%)$ & 1,6774 & 3.03 & 3.36 & 2.01 & 1.68 & 1.35 & 2.69 & 0.67 & 9.40 & Rendah \\
\hline 3. & $\mathrm{pH}$ & & 7,45 & 7.68 & 7.44 & 7.5 & 7.5 & 7.63 & 7.24 & 7.34 & 7.11 & Netral \\
\hline 4. & $C$ & $(\%)$ & 0,533 & 0.53 & 0.60 & 0.499 & 0.437 & 0.764 & 0.636 & 0.51 & 0.386 & Rendah \\
\hline 5. & $\mathrm{BO}$ & $(\%)$ & 0,918 & 0.91 & 1.04 & 0.86 & 0.753 & 1.317 & 1.097 & 0.879 & 0.666 & Rendah \\
\hline 6. & $\mathrm{~N}$ & $(\%)$ & 0,019 & 0.06 & 0.06 & 0.05 & 0.05 & 0.07 & 0.08 & 0.10 & 0.072 & Rendah \\
\hline 7. & $\mathrm{C} / \mathrm{N}$ & -- & 28,275 & 9.35 & 10.03 & 9.38 & 8.91 & 10.12 & 7.66 & 5.01 & 5.39 & Rendah \\
\hline 8. & $\mathrm{P}$ & (ppm) & 89,52 & 42.05 & 43.37 & 54.80 & 53.19 & 81.32 & 77.98 & 64.48 & 72.33 & Tinggi \\
\hline 9. & K & (ppm) & 926,565 & 972 & 942 & 959 & 946 & 795 & 1019 & 1462 & 912 & Tinggi \\
\hline 10. & $\mathrm{Cu}$ & (ppm) & 4,51 & 12.85 & 10.61 & 9.64 & 8.77 & 17.25 & 7.77 & 8.01 & 5.33 & Rendah \\
\hline 11. & $\mathrm{~Pb}$ & (ppm) & 16,74 & 28.37 & 21.21 & 24.34 & 18.81 & 30.23 & 14.34 & 16.53 & 13.30 & Rendah \\
\hline
\end{tabular}

kadar bahan organik tertinggi terjadi pada perlakuan B1P1 (1.317\%) yaitu pemberian kompos 1,5 kg/tanaman, dan pupuk hayati yang mengandung bakteri Azotobacter sp. dan Psedomonas sp.

Pemberian pupuk hayati yang mengandung Azotobacter sp dan Pseudomonas sp telah mampu meningkatkan kadar $\mathrm{N}$ dalam tanah, karena Azotobacter $\mathrm{sp}$ merupakan bakteri aerob yang dapat memfiksasi $\mathrm{N}$ dari udara sehingga tersedia di dalam tanah. Meningkatnya hara $\mathrm{N}$ di dalam tanah akan menaikkan kadar $\mathrm{N}$ tanah yang dapat digunakan oleh tanaman untuk membentuk klorofil daun ${ }^{5}$. karena meningkatnya kadar $\mathrm{N}$ dalam tanah disertai dengan kondisi $\mathrm{C}$ dalam tanah yang tetap tidak berubah secara signifikan setelah pemberian pupuk hayati dan kombinasi kompos sampah kota dengan pupuk N P K. Kemasaman tanah dan bahan organik dalam tanah setelah pemberian pupuk hayati, kompos sampah kota dan pupuk N P K tidak mengalami perubahan.

Nilai C/N sebelum penelitian 28,275 , nilai tersebut diatas 15 , berarti bahwa bahan organik belum terdekomposisi secara sempurna sehingga memerlukan waktu untuk mendukung pertumbuhan tanaman. Sedang nilai $\mathrm{C} / \mathrm{N}$ setelah penelitian dengan 
diberi bahan pengkondisi tanah (pupuk kompos) nilai $\mathrm{C} / \mathrm{N}$ berkisar antara 5,01 10,12 . Nilai tersebut kurang dari 11 , berarti bahwa bahan organik dalam tanah sudah sangat melapuk.

\section{4) Kandungan $\mathbf{P}$ dan $\mathrm{K}$ Tersedia}

Unsur hara phosfor ( $\mathrm{P}$ ) merupakan hara makro penting setelah unsur hara $\mathrm{N}$, hara phosfor diserap dari tanah dalam bentuk $\mathrm{H}_{2} \mathrm{PO}_{4}$ - dan atau $\mathrm{HPO}_{4}{ }_{4}^{2-}$. Kadar hara P-tersedia yang tinggi akan menguntungkan bagi tanaman, tanah cenderung lebih subur. Tidak ada unsur lain yang dapat menggantikan fungsinya di dalam tanaman, sehingga tanaman harus mendapatkan unsur hara $P$ secara cukup untuk pertumbuhannya. Fungsi penting phosfor di dalam tanaman yaitu dalam proses fotosintesis, respirasi, transfer dan penyimpanan energi, pembelahan dan pembesaran sel serta proses-proses yang lainnya.

Kalium merupakan unsur hara ketiga setelah $\mathrm{N}$ dan $\mathrm{P}$ yang dibutuhkan tanaman dalam jumlah banyak dan berperan penting dalam proses fotosintesa, pembentukan karbohidrat dan protein. Pemupukan kalium pada lahan pertanian kering baik padi maupun jagung serta umbi-umbian menunjukkan hasil yang nyata, apabila pupuk nitrogen dan phosfor diberikan dalam jumlah yang cukup, tetapi bila terjadi konsumsi kalium yang berlebihan, maka konsentrasi kalium dalam jaringan tumbuhan meningkat, akibatnya translokasi kation lain terutama $\mathrm{Mg}$ akan terganggu sehingga terjadi penurunan kadar $\mathrm{Mg}$ dalam daun sedemikian rendahnya sehingga fotosintesa akan terganggu. Sebaliknya bila kadar $\mathrm{Mg}$ dalam tanah dalam jumlah tinggi, maka kadar $\mathrm{K}$ yang tersedia bagi tanaman akan menurun, karena difiksasi oleh koloid tanah atau tercuci bersama air drainase (curah hujan tinggi $)^{5}$. Tanaman yang kekurangan hara Kalium $(\mathrm{K})$, batangnya tidak kuat, daun terkulai dan cepat menua, mudah terserang hama dan penyakit.
Hara phospor $(\mathrm{P})$ dan kalium $(\mathrm{K}) \mathrm{di}$ wilayah studi tergolong sangat tinggi. Nilai phospor $(\mathrm{P})$ berkisar antara $42.05 \mathrm{ppm}-81.32$ ppm, kadar phospor terendah terdapat pada perlakuan B0P1 (kompos tanpa pupuk hayati dan tanpa pupuk NPK), sedangkan yang tertinggi dicapai pada perlakuan B1P1 (kompos ditambah pupuk hayati, tanpa pemberian pupuk NPK). Posphor berguna untuk merangsang pertumbuhan akar, phospor juga berfungsi membantu asimilasi, mempercepat bunga, pemasakan biji dan buah.

Sedang nilai Kalium di wilayah studi berkisar antara 795 ppm - 1462 ppm, kadar Kalium terendah diperoleh pada perlakuan dengan pemberian pupuk kompos tanpa pupuk hayati, sedang tertinggi dicapai pada perlakuan kompos dengan penambahan pupuk hayati. Unsur kalium berperan dalam memperkuat tubuh tanaman agar daun, bunga dan buah tidak mudah gugur, dan kalium adalah merupakan sumber kekuatan bagi tanaman dalam menghadapi kekeringan dan penyakit tanaman. Apabila tanah dengan kandungan unsur kalium rendah menyebabkan daun tanaman keriting, mengerut, timbul bercak merah coklat, mengering dan akhirnya mati. Dari perlakuan pemberian pupuk hayati (Azotobacter sp. dan Psedomonas sp.) ternyata dapat meningkatkan hara phospor dan kalium dalam tanah dibandingkan dengan perlakuan tanpa pupuk hayati

\section{5) Kapasitas Pertukaran Kation (KPK)}

Secara fisik lahan pasir pantai memiliki porositas tanah yang besar, menyebabkan tanah pasiran bersifat aerob sehingga perombakan bahan organik dalam tanah berjalan cepat dan berakibat rendahnya ketersediaan bahan organik di dalam tanah. Bahan organik tanah yang rendah berpengaruh besar terhadap kadar lengas dan kapasitas pertukaran kation (KPK) tanah. KPK tanah yang rendah dapat mempengaruhi penyerapan unsur hara maupun mineral di dalam tanah oleh tanaman. Kondisi aerob 
tanah pasiran menyebabkan nitrifikasi berjalan intensif sehingga $\mathrm{N}$ membentuk $\mathrm{NO}^{-}$lebih besar dibandingkan $\mathrm{NH}^{+}$hal ini menyebabkan kehilangan $\mathrm{N}$ yang lebih besar akibat pelindihan. Namun, lahan pasir memiliki tingkat kemasaman tanah yang netral sehingga tidak menjadi penghambat dalam pertumbuhan tanaman. Oleh karena itu, untuk meningkatkan pertukaran kation dibutuhkan penambahan bahan organik dalam tanah.

Dari hasil analisis laboratorium, kapasitas pertukaran kation (KPK), bahan organik, kadar lengas, dan hara $\mathrm{N}$ di wilayah studi sangat rendah, tetapi memiliki kadar $\mathrm{C} / \mathrm{N}$, hara $\mathrm{P}$ dan $\mathrm{K}$ tinggi dengan kondisi kemasaman tanah netral. Kandungan logam Cu sebesar 4,51 ppm dan $\mathrm{Pb}$ sebesar 16,74 ppm pada tanah asal menurut Peterson \& Alloway (1979) dalam Charlena (2004) tergolong rendah ${ }^{5}$.

Pemberian pupuk hayati (BIOCON) yang mengandung bakteri Azotobacter sp dengan penambahan pupuk N, P, K sejumlah 80 gram/tanaman ternyata belum dapat meningkatkan hara $\mathrm{N}$ dalam tanah sehingga kebutuhan $\mathrm{N}$ oleh tanaman belum dapat terpenuhi. Pemberian pupuk hayati akan sangat berpengaruh sebagai penyedia hara $\mathrm{N}$ dalam tanah. Hal ini dipengaruhi oleh kompos sampah kota yang diberikan masih memiliki nisbah C/N tinggi. Rendahnya kadar $\mathrm{N}$ menjadi pembatas dalam aktivitas mikroorganisme dalam tanah, karena dapat menimbulkan persaingan antara mikroorganisme maupun dengan tanaman yang menyebabkan penurunan kadar $\mathrm{N}$ dalam tanah. Pencemaran logam $\mathrm{Cu}$ dan $\mathrm{Pb}$ yang tinggi berpengaruh terhadap populasi mikroorganisme terutama bakteri aerob.

Secara keseluruhan dari hasil analisis kualitas kimia tanah pasiran di pantai Patihan, Kabupaten Bantul dapat digolongkan miskin unsur hara dengan kesuburan yang sangat rendah. Untuk meningkatkan kesuburannya sangat dibutuhkan penambahan pupuk sebagai sumber hara, terutama kompos dan pupuk hayati sebagai sumber bahan organik.

\subsection{Akumulasi Logam $\mathrm{Cu}$ dan $\mathrm{Pb}$ pada Tanaman Jarak Pagar}

Metode yang dapat digunakan untuk membersihkan pencemaran adalah dengan memanfaatkan tanaman yang disebut Fitoremediasi. Ada 2 jenis tanaman fitoremediasi yaitu, yang memiliki kemampuan sangat tinggi dalam mengangkut berbagai pencemaran yang ada (multiple uptake hyperaccumulator plant) ataupun tanaman yang memiliki kemampuan mengangkut pencemaran yang bersifat tunggal (spesific uptake hyperaccumulator plant). Tanaman hiperakumulator yang telah ditemukan hingga saat ini mencakup sekitar 400 spesies, bukan hanya mampu membersihkan metal (logam), non-logam, metaloid, tetapi juga senyawa organik. Tanaman dikatakan hiperakumulator apabila tanaman tersebut mampu menyerap logam Mn, Zn, Ni lebih dari 10.000 ppm unsur- unsur tersebut, lebih dari 1.000 ppm untuk Cu dan Se, dan harus lebih dari $100 \mathrm{ppm}^{7}$.

Adabeberapakriteriaagartanaman dapat disebut sebagai suatu hiperakumulator, yaitu apabila tanaman mampu mentranslokasikan unsur (baik tunggal ataupun berbagai macam unsur) ke pucuk tanaman lebih tinggi dari translokasi yang terjadi di akar. Tanaman yang hanya dapat beradaptasi baik pada tanah-tanah tercemar tetapi tidak adanya kemampuan tanaman tersebut mentranslokasikan serapan unsur ke pucuk tanaman tidak dapat digolongkan sebagai tanaman hiperakumulator,

Tanaman dapat pula dikriteriakan sebagai hiperakumulator, apabila nilai bioakumulasi unsur tersebut adalah lebih besar dari nilai 1, di mana nilai bioakumulasi dihitung dari konsentrasi unsur tersebut di pucuk (shoot concentration) dibagi konsentrasi unsur di dalam tanah (defined as shoot concentration/total soil concentration) (7).

Berdasarkan mekanisme detoksifikasi, terdapat 4 cara untuk mengisolasi logam berat, yakni: fitoekstraksi, rizofiltrasi, 
fitostabilasi, dan remediasi oleh tanaman yang dibantu mikroba ${ }^{8)}$. Dalam penelitian ini untuk membersihkan logam berat yang terdapat pada pupuk kompos TPA dan mengisolasi bakteri dalam zona perakaran maka mencoba dengan mengkombinasikan metode fitoremediasi (tanaman jarak pagar) dan fitostabilisasi (bantuan bakteri (Azotobacter sp. dan Psedomonas $s p$.). Fitoremediasi dimaksudkan untuk menurunkan mobilitas logam berat dengan cara penambahan bahan pembenah (pengkondisi tanah) berupa bahan organik yang dapat meningkatkan aras pengikatan logam oleh tanah, dengan pelepasan protein atau enzym oleh akar yang menyebabkan pengendapan atau imobilisasi logam baik pada permukaan akar atau dalam tanah ${ }^{8}$.

Tembaga $(\mathrm{Cu})$ salah satu unsur hara mikro yang ketersediaannya mutlak diperlukan oleh tanaman, yang berfungsi sebagai anasir protein kloroplas dan sebagai bagian dari sistem transport elektron. Sedangkan timbal $(\mathrm{Pb})$ merupakan logam yang tidak termasuk hara esensial tanaman, karena sejauh ini belum diketahui manfaat hara $\mathrm{Pb}$ dalam metabolisme tanaman. Rerata hasil akumulasi logam $\mathrm{Cu}$ pada jaringan buah dan logam $\mathrm{Pb}$ pada jaringan daun tanaman jarak pagar ditunjukkan pada Tabel 3 dan Tabel 4.

Tabel 3. Rerata Akumulasi Logam Cu (ppm) pada Jaringan Tanaman Jarak Pagar Umur 24 MST

\begin{tabular}{|c|c|c|c|c|}
\hline \multirow{2}{*}{ No. } & \multirow{2}{*}{$\begin{array}{c}\text { Kompos TPA: } \\
\text { Pupuk NPK }\end{array}$} & \multicolumn{2}{|c|}{$\begin{array}{c}\text { Perlakuan } \\
\text { Hayati }\end{array}$} & $\begin{array}{c}\text { Ppk } \\
\text { Hayati }\end{array}$ \\
\hline 1. & P1 $(1: 0)$ & 32,05 & 12,76 & 22,41 \\
\hline 2. & P2 $(2 / 3: 1 / 3)$ & 18,33 & 8,50 & 13,41 \\
\hline 3. & P3 $(1 / 3: 2 / 3)$ & 25,96 & 37,42 & 31,69 \\
\hline 4. & P4 $(0: 1)$ & 46,60 & 16,30 & 31,45 \\
\hline & Rerata & 30,73 & 18,75 & \\
\hline
\end{tabular}

Logam $\mathrm{Cu}$ merupakan hara mikro yang essensial bagi metabolisme tanaman, akan tetapi ketersedian logam $\mathrm{Cu}$ dan $\mathrm{Pb}$ yang berlebihan dapat menyebabkan toksik bagi tanaman. Pemberian pupuk hayati mengandung Azotobacter sp dan Pseudomonas sp mampu mengurangi akumulasi logam $\mathrm{Cu}$ dan $\mathrm{Pb}$ ke dalam jaringan tanaman, karena Pseudomonas sp merupakan bakteri anaerob yang memiliki ketahanan terhadap logam $\mathrm{Cu}$. Pengikatan logam Cu oleh Pseudomonas $\mathrm{sp}$ dengan pembentukan kompleks logam organik sehingga terjadi pengkelatan logam berat. Emtiazi dkk. (2004) melaporkan bahwa bakteri Azotobacter sp. dapat memproduksi polimer yang mempunyai kemampuan dalam mengikat logam seperti $\mathrm{Cu}$ (jumlah kecil)9).

Dari Tabel 3 menunjukkan bahwa pemberian pupuk hayati secara tunggal mampu menghambat akumulasi logam $\mathrm{Cu}$ pada jaringan daun tanaman jarak pagar. Pada perlakuan kombinasi pupuk kompos sampah kota dengan pupuk N, P, $\mathrm{K}$ baik secara interaksi maupun tunggal menunjukkan pengaruh yang tidak nyata terhadap akumulasi logam $\mathrm{Cu}$ pada daun dan buah jarak pagar (Jatropha curcas L.).

Tabel 4. Rerata Akumulasi Logam Pb (ppm) pada Jaringan Tanaman Jarak Pagar Umur 24 MST

\begin{tabular}{|l|l|l|r|l|}
\hline \multirow{2}{*}{ No. } & \multicolumn{1}{|c|}{$\begin{array}{c}\text { Kompos } \\
\text { TPA: Pupuk } \\
\text { NPK }\end{array}$} & \multicolumn{2}{|c|}{ Perlakuan } & \multirow{2}{*}{ Non Ppk } \\
\cline { 3 - 4 } Hayati & $\begin{array}{c}\text { Ppk } \\
\text { Hayati }\end{array}$ & \\
\hline 1. & P1 $(1: 0)$ & 43,76 & 12,35 & 28,06 \\
\hline 2. & P2 $(2 / 3: 1 / 3)$ & 18,42 & 16,40 & 17,41 \\
\hline 3. & P3 $(1 / 3: 2 / 3)$ & 16,40 & 16,40 & 16,40 \\
\hline 4. & P4 $(0: 1)$ & 41,93 & 14,37 & 28,15 \\
\hline & Rerata & 30,12 & 14,88 & \\
\hline
\end{tabular}

Kandungan $\mathrm{Pb}$ pada jaringan tanaman jarak menunjukkan banyaknya $\mathrm{Pb}$ yang terakumulasi pada jaringan tanaman tersebut. Dengan mengetahui banyaknya kandungan 
$\mathrm{Pb}$ pada jaringan tanaman jarak maka dapat diketahui kemampuan tanaman jarak pagar dalam mengakumulasi $\mathrm{Pb}$. Serapan $\mathrm{Pb}$ jarak pagar pada perlakuan pemberian pupuk hayati Hal ini disebabkan aktifitas bakteri dari pupuk hayati yang mampu mensekresikan asam-asam organik berberat molekul rendah yaitu asam sitrat dan malat yang dihasilkan melalui siklus krebs.

Dalam mentranslokasikan logam berat $(\mathrm{Cu}$ dan $\mathrm{Pb})$ ke pucuk tanaman, ternyata perlakuan tanpa pupuk hayati lebih tinggi daripada perlakuan yang menggunakan pupuk hayati (Azotobacter sp. dan Psedomonas sp.). Rerata akumulasi logam berat $\mathrm{Cu}$ pada perlakuan tanpa pupuk hayati sebesar 30,73 ppm, sedang pada perlakuan dengan pemberian pupuk hayati kandungan logam $\mathrm{Cu}$ sebesar 18,75 ppm. Jadi kurang lebih $50 \%$ logam Cu yang masih tertahan pada zone perakaran, hal ini karena pengaruh aktifitas pupuk hayati (Azotobacter sp. dan Psedomonas sp.).

Seperti halnya logam $\mathrm{Cu}$, rerata logam $\mathrm{Pb}$ yang terakomulasi pada jaringan daun dan buah tanaman jarak pagar memperlihatkan bahwa, perlakuan tanpa pupuk hayati dapat lebih banyak mentranslokasikan unsur tersebut dari pada perlakuan yang diberi pupuk hayati. Rerata akumulasi logam $\mathrm{Pb}$ dengan perlakuan tanpa pupuk hayati sebesar 30,12 ppm, sedang yang diberi pupuk hayati sebesar 14,88 ppm, kurang lebih sama dengan yang diperlihatkan pada unsur logam $\mathrm{Cu}$, yaitu $50 \%$ logam $\mathrm{Pb}$ yang tertahan pada zone perakaran.

Hal ini mengindikasikan bahwa dalam mentranslokasi logam berat $\mathrm{Cu}$ dan $\mathrm{Pb}$ dari dalam tanah, tanaman jarak pagar telah teruji sebagai tanaman fitoremediasi. Sebaliknya pemberian pupuk hayati (Azotobacter $s p$. dan Psedomonas sp.), telah mampu meningkatkan aras pengikatan logam dengan melepaskan protein oleh akar tanaman yang menyebabkan pengendapan logam pda permukaan akar atau dalam tanah.

Penerapan teknologi remediasi dalam rangka pemulihan lingkungan dari pencemaran dapat disesuaikan dengan maksud dan tujuannya. Teknologi fitoremediasi lebih sesuai untuk membersihkan lahan dari tercemar logam berat, namun fitostabilisasi cenderung lebih murah dan dapat meningkatkan kesuburan tanah dan memelihara ekosistem, karena selain pencemaran yang mampu diangkut oleh tanaman, tanah secara signifikan juga akan mengalami perbaikan bukan hanya karena berkurangnya pencemaran tetapi juga akibat adanya aktivitas akar. Tanah secara otomatis menjadi lebih subur karena akar tanaman meregulasikan dirinya mengeluarkan asam-asam organik yang mampu meningkatkan kesuburan kimia, fisika, dan juga biologi tanah.

\section{KESIMPULAN}

1. Pemberian pupuk kompos dari sampah kota (TPA) serta pupuk hayati Azotobacter sp dan Pseudomonas sp, telah dapat meningkatkan kesuburan tanah dengan meningkatnya kandungan unsur hara dalam tanah

2. Pemberian kompos sampah kota (TPA) mampu menggantikan peran pupuk $\mathrm{N}, \mathrm{P}, \mathrm{K}$ sebagai sumber hara dalam mendukung pertumbuhan tanaman jarak pagar (Jatropha curcas L.) yang ditanam di lahan pasir pantai.

3. Tanaman jarak pagar ( Jatropha curcas L.), dapat digolongkan sebagai tanaman fitoremediasi

4. Pupuk hayati mampu menghambat akumulasi logam tembaga (Cu) dan timbal $(\mathrm{Pb})$ ke dalam jaringan tanaman jarak pagar (Jatropha curcas L.), sehingga logam berat tersebut tetap berada di dalam tanah (zone perakaran).

\section{DAFTAR PUSTAKA}

1. Yuwono, N. W. (2006). Pupuk Organik dan Hayati dalam Pertanian Organik. 
Fakultas Pertanian Universitas Gadjah Mada. Yogyakarta.

2. Supriyambodo, P. (1994). Pengaruh Penggunaan Sari Kering Limbah Industri Penyamakan Kulit sebagai Pupuk Organik terhadap Pertumbuhan Bayam (Amaranthus Spinosus L.) dan Penyerapan Cr pada Tanah Vertisol dan Regosol. Tesis. Fakultas Pertanian UGM. Yogyakarta.

3. Prijambada, (2006). Bioteknologi untuk Penanganan Limbah Logam Berat. Makalah dalam Bioteknologi dan Kelestarian Lingkungan. Universitas Sebelas Maret.

4. Notohadiprawiro, T. (1995). Logam berat dalam pertanian. J. Manusia dan Lingkungan. 7 (2).

5. Charlena (2004). Pencemaran Logam Berat Timbal $(\mathrm{Pb})$ dan Cadmium (Cd) pada Sayur-sayuran. Program Pasca sarjana /S3/ Institut Pertanian Bogor.
6. Prijambada, I.D., D. Wahjuningrum dan J. Soedarsono. (1999). Effect of fluorescent pseudomonads rhizospheric colonization on cadmium accumalation by indian mustard (Brassica juncea). Journal of Bioscience.

7. Aiyen (2005). Peneliti Fitoremediasi Tanah Tercemar Logam Berat Pb dan Cd dengan Menggunakan Tanaman Jarak Pagar (Jatropha Curcas Linn). Fakultas Pertanian Universitas Tadulako, Palu. Sumber: http://www. kompas.com/kompas-cetak/0503/04/ ilpeng/1592821.htm

8. Fitoremediasi Logam Berat Lahan Persawahan di Kecamatan Jaten, Kabupaten Karanganyar, Jawa Tengah. Laboratorium Mikrobiologi Tanah dan Lingkungan, Fakultas Pertanian, UGM. dengan Kementerian Lingkungan Hidup.

9. Emtiazi, G., Z. Ethemadifar, dan M. H. Habibi. 2004. Production of extra-celluler polymer in Azotobacter and and biosorption of metal by exopolymer. Afr. J. Biotechnol. 